\title{
PENGEMBANGAN MODUL INVENTARISASI TANAMAN OBAT PADA SISTEM INFORMASI TANAMAN OBAT BENGKULU
}

\author{
Della Maulidiya $^{1}$, Kasrina $^{2}$ \\ ${ }^{1,2}$ Fakultas Keguruan dan Ilmu Pendidikan Universitas Bengkulu \\ Jl. WR. Supratman Kandang Limun Bengkulu 38371 A \\ 1della_maulidiya@yahoo.com
}

\begin{abstract}
The amount of information that has resulted from research in the field of study of medicinal plants wether related to the identification, chemical content, the benefits of medication and how to use as a drug need to be informed to the public. One way that can be done is to build a web based information system for medicinal plant that can be accessed via internet. This research aims to develop an inventory module of medicinal plants identified in Bengkulu City. This module is one of the modules that exist in Bengkulu Medicinal Plant Information System (SITOBELU). The methodology used for the development is Rational Unified Process (RUP). Data collection techniques include literature study and field study. The results of literature studies are in the form of data of medicinal plants that have been inventoried either based on taxonomy, name index, and treatable diseases. The result of field study is the identification of planting location and way of utilization of medicinal plant in Bengkulu City.
\end{abstract}

Keywords: medicinal plants, information system, medicinal plant inventory module, content-based image retrieval

INTISARI

Banyaknya informasi yang telah dihasilkan dari penelitian di bidang kajian tanaman obat baik terkait identifikasi, kandungan kimia, manfaat pengobatan dan cara pemanfaatan sebagai obat perlu diinformasikan kepada masyarakat. Salah satu cara yang dapat dilakukan yaitu dengan cara membuat suatu sistem informasi tanaman obat berbasis web yang dapat diakses melalui internet. Penelitian ini bertujuan untuk mengembangkan modul inventarisasi tanaman obat yang teridentifikasi keberadaannya di Kota Bengkulu. Modul ini merupakan salah satu modul yang ada dalam Sistem Informasi Tanaman Obat Bengkulu (SITOBELU). Metodologi yang digunakan untuk pengembangan yaitu Rational Unified Process (RUP). Teknik pengumpulan data meliputi studi pustaka dan studi lapang. Hasil studi pustaka berupa data tanaman obat yang telah terinventarisasi baik berdasarkan taksonomi, indeks nama, dan penyakit yang dapat diobati. Hasil studi lapang yaitu identifikasi lokasi penanaman dan cara pemanfaatan tanaman obat di Kota Bengkulu.

Kata Kunci: tanaman obat, sistem informasi, modul inventarisasi tanaman obat, content-based image retrieval

\section{PENDAhUluan}

Sastrapraja (1980) dalam Heyne (1987) menyebutkan bahwa tumbuhan atau tanaman obat adalah tumbuhan yang salah satu, beberapa atau seluruh bagian tumbuhan tersebut mengandung zat atau bahan aktif yang berguna untuk kesehatan tubuh, penyembuhan penyakit maupun bahan kosmetik. Sedangkan menurut Handayani (2003) tumbuhan obat adalah seluruh jenis tumbuhan yang diketahui atau dipercaya mempunyai khasiat obat.

Beberapa penelitian menunjukkan bahwa masyarakat adat masih cenderung mempertahankan untuk menggunakan tumbuhan obat untuk memenuhi kebutuhan obat mereka. Sebagai contoh, hasil penelitian Nurhamidah dan Kasrina (2006) menunjukkan ada 99 jenis tumbuhan khusus untuk tanaman penunjang fertilitas yang dimanfaatkan oleh masyarakat kota Bengkulu. Penelitian yang sama juga mengkaji tumbuhan obat dalam naskah kuno suku Serawai dan didapatkan 63 jenis tanaman yang dimanfaatkan masyarakat Serawai. Hal ini dapat dilihat bahwa Suku Serawai di Propinsi Bengkulu, menyimpan pengetahuan tentang pemanfaatan tumbuhan sebagai obat dalam tulisan atau dokumen empat naskah kuno yang disebut dengan naskah KaGa-Nga. Pemakaian tumbuhan dalam pengobatan ada pemakaian tunggal dan ada yang berupa ramuan. Hasil penelitian-penelitian ini menunjukkan bahwa penggunaan bahan-bahan obat alami masih menjadi pilihan bagi masyarakat.

Tingginya minat dan kesadaran masyarakat terhadap pengobatan tradisional menggunakan berbagai tanaman obat dipengaruhi oleh unsur ekonomis dan ketersediaan informasi yang tak terbatas baik melalui buku maupun media massa. Penelitian di bidang kajian tanaman obat juga semakin gencar dilakukan. Berbagai informasi terkait karakteristik, fitokimia, dan pemanfaatan tanaman obat tersebut perlu terus dipublikasikan kepada masyarakat. Salah satu cara pengelolaan informasi tanaman obat yaitu melalui sebuah sistem informasi berbasis web yang dapat diakses melalui internet.

Pemerintah telah mengupayakan pembuatan Bank Data Obat Bahan Alam Indonesia yang dibuat dan dikelola oleh Badan Pengawas Obat dan Makanan 
(http://www.pom.go.id/index.php/oai). Informasi yang tersedia meliputi agenda kerjasama Badan POM dengan berbagai institusi dan perguruan tinggi terkait penelitian tanaman obat, hayati bahan obat, publikasi artikel ilmiah, perkembangan penelitian tanaman obat, dan taksonomi tanaman obat.

Hal serupa juga dilakukan oleh Balai Jaringan Informasi Ilmu Pengetahuan dan Teknologi (Balai IPTEKnet) BPPT melalui websitenya yang membuat pangkalan data berisi daftar tanaman obat Indonesia (http://www.iptek.net.id/ind/pd_tanobat). Pangkalan data tersebut menggunakan indeks nama tanaman dan nama penyakit sebagai kata kunci pencarian dan pelacakan data. Data yang tersedia merupakan hasil kerjasama IPTEKnet dengan CODATA ICSU Indonesia.

Penelitian ini bertujuan untuk mengembangkan modul inventarisasi tanaman obat yang teridentifikasi keberadaannya di Kota Bengkulu. Modul dikembangkan dengan menggunakan prinsip CBIR sehingga selain taksonomi, karakteristik, fitokimia, dan manfaat tanaman obat, modul juga menginventarisasi foto-foto tanaman obat. Penelitian ini difokuskan pada CBIR dengan menggunakan citra digital daun tanaman.

\section{TINJAUAN PUSTAKA}

Sistem informasi menurut Buckingham et.al(1987) dalam [1] didefinisikan sebagai sebuah sistem yang mengumpulkan (assemble), menyimpan (store), mengolah (process), dan menyampaikan (deliver) informasi yang relevan dengan suatu organisasi (atau komunitas) sedemikian sehingga informasi tersebut dapat diakses dan berguna bagi siapa pun yang menggunakannya. Sebuah sistem informasi merupakan sistem aktivitas (sosial) manusia.

Hendrik dan Rahman (2011) telah mengembangkan sebuah prototipe sistem informasi tanaman obat Indonesia berbasis web. Pengembangan sistem tersebut dilakukan dengan menggunakan pendekatan mesh-up yang menekankan proses agregasi data menggunakan model Linked Data. Konten diperoleh dengan cara mengakses suatu SPARQL endpoint yang berisi data-data tanaman obat Indonesia berdasarkan referensi Atlas Tumbuhan Obat Indonesia, Jilid I-VI, karangan dr. Setiawan Dalimartha. SPARQL endpoint dibuat oleh Hendrik dan Rahman (2011) dengan memanfaatkan server D2R yang memungkinkan data mapping dari basisdata relasional menjadi model data RDF. Hendrik dan Rahman (2011) menggunakan bahasa pemrograman PHP dan MySQL sebagai Database Management Systems (DBMS).

Hasil penelitian Hendrik dan Rahman (2011) menunjukkan bahwa Linked Data dapat dilihat sebagai suatu basis data global yang memberikan banyak keuntungan di antaranya adalah kemudahan untuk berbagi pakai dan menggunakan ulang data. Namun kualitas data tergantung pada penyedia data set dan reliabilitas sistem juga sangat tergantung pada reliabilitas SPARQL endpoint. Jika penyedia senantiasa memutakhirkan data, maka aplikasi juga senantiasa memperoleh data yang mutakhir. Di samping itu, sistem yang dikembangkan Hendrik dan Rahman (2011) hanya menyediakan fasilitas pencarian berdasarkan penyakit, nama daerah, nama asing, suku, familia, simplisia, dan urutan abjad.

Di Malaysia, Noraziah dkk. (2011) telah mengembangkan Medicinal Herbs Information System (MHIS) dalam bentuk web-based application system berdasarkan Rational Unified Process (RUP). RUP adalah sebuah proses pengembangan perangkat lunak secara iterative yang dikembangkan oleh Rational Software Cooperation di IBM. RUP terdiri atas empat fase siklus di mana setiap fase meliputi banyak iterasi. Keempat fase yang digunakan dalam MHIS yaitu: inception phase, elaboration phase, construction phase, dan transition phase. MHIS menyediakan tiga tabel untuk menyimpan data yakni tabel untuk menyimpan informasi tanaman obat, tabel untuk menyimpan tambahan komentar atau pun request dan tabel login. Informasi tanaman obat yang digunakan meliputi nama lokal, nama ilmiah, nama famili, kegunaan, ciri-ciri fisik, dan gambar tanaman obat. Namun MHIS yang dikembangkan Noraziah (2011) tersebut hanya menggunakan pilihan pencarian berdasarkan nama ilmiah saja.

Galingging dan Bhermana (2010) telah melakukan pewilayahan secara geografis untuk lima jenis tanaman obat berdasarkan hasil kajian eksplorasi plasma nutfah tanaman obat yang terdapat di wilayah Kalimantan Tengah. Tahap awal penelitian mereka yakni kegiatan eksplorasi yang bertujuan untuk menginventarisasi data dan informasi keberadaan tanaman obat langka. Data dan informasi yang dikumpulkan Galingging dan Bhermana (2010) meliputi daerah asal atau lokasi penemuan, jenis dan karakterisasi secara ex-situ, manfaat dan khasiatnyasebagai obat termasuk peluang untuk budidaya dan perbanyakan. Informasi tersebut dikarakterisasi baik secara kualitatif dan kuantitatif dengan mengacu standarisasi pada descriptor list atau pedoman yang berasal dari Balai Penelitian Tanaman Rempah dan Obat (Bogor). Karakterisasi yang dilakukan salah satunya untuk mengidentifikasi habitus tanaman obat yang dipilih. Galingging dan Bhermana (2010) juga melakukan pengujian kandungan biofarmaka sebagai obat. 
Sistem informasi tanaman obat yang telah diuraikan sebelumnya masih mengandalkan penggunaan teks sebagai dasar untuk perolehan kembali informasi (information-retrieval) dari basis data. Teknik retrieval ini belum dapat memenuhi kebutuhan pengguna terutama masyarakat awam yang belum mengetahui nama umum atau nama latin tanaman obat. Salah satu cara yang dapat digunakan pengguna untuk memastikan tanaman yang dikenalnya sebagai obat secara turun temurun adalah dengan membandingkan foto tanaman yang ia punya dengan foto tanaman yang tersedia dalam basis data. Teknik ini dinamakan content-based image retrieval (CBIR)

Teknologi CBIR berkembang didasari munculnya kebutuhan informasi yang harus diperoleh dari citra (gambar) digital. Jenis informasi yang diinginkan dari citra antara lain : ilustrasi dari teks artikel yang sulit diungkapkan dalam kata-kata, menampilkan data rinci untuk analisis misalnya citra radiologi, dan perekaman formal dari data rancangan yang akan digunakan untuk proses berikutnya misalnya rancangan arsitektur. Informasi yang dapat diperoleh dari citra selanjutnya dapat dikategorikan dalam tiga kategori umum yaitu color (warna), shape (bentuk), dan texture (tekstur). Datta dkk. (2008) dalam Galingging dan Bhermana (2010) mendefinisikan CBIR sebagai sebuah teknologi yang membantu dalam mengorganisasikan arsip citra digital berdasarkan visual content tiap citra.

Sistem CBIR menurut Datta dkk. (2008) dalam Galingging dan Bhermana (2010) umumnya melakukan ekstraksi fitur sebagai langkah pra-proses Setelah fitur-fitur visual diperoleh dari hasil ekstrasi, selanjutnya digunakan sebagai masukan (input) untuk analisis citra baik untuk pendugaan similaritas, deteksi konsep, atau pun annotation.

Proses pertama yang perlu dilakukan untuk ekstraksi dan memproses/konstruksi fitur adalah image segmentation. Tujuan utama image segmentation adalah melakukan karakterisasi bentuk yang ada dalam citra. Contoh cara segmentasi yang banyak digunakan antara lain pendekatan k-means clustering, hidden Markov random fields, expectation-maximization (EM) algorithm, spectral clustering, mean shift procedure, multiresolution segmentation of low-depth-of-field images, Bayesian framework- based segmentation, dan EM-algorithmbased segmentation using a Gaussian mixture model. Di samping itu, pendekatan sequential segmentation juga dapat dilakukan untuk image segmentation di mana pendekatan ini dilakukan dengan menggunakan fitur tekstur dan warna.

Setelah image signature diperoleh langkah berikutnya melakukan perhitungan untuk menentukan similaritas. Similaritas suatu citra ditentukan berdasarkan signature masing-masing citra. Contoh formula matematika untuk pengukuran jarak yang umum digunakan dalam CBIR untuk pengukuran similaritas antara lain : Euclidean ( $\mathrm{L}^{2}$ norm), Weighted Euclidean, Hausdorff, Mallows, IRM (integrated region matching), dan K-L divergence. Teknik yang digunakan untuk proses tersebut tergantung dari jenis signature yang diperoleh.

CBIR yang memiliki basis data citra berukuran sangat banyak tidak efektif (lambat dan kurang akurat) jika hanya mengandalkan hasil pengukuran similaritas citra. Karena itu dikembangkan learningbased techniques sehingga diperoleh image classification (image categorization). Proses image categorization tidak hanya mengandalkan similaritas namun juga melakukan pendugaan query (kriteria permintaan pengguna) melalui proses training terhadap kumpulan citra yang ada dalam basis data. Contoh formula yang dapat digunakan untuk mage categorization antara lain SVM, MIL (multipleinstance learning), statistical models, Bayesian classifiers, k-NN, dan trees.

\section{RANCANGAN PENELITIAN}

Penelitian ini telah melakukan pengembangan sistem informasi dengan menggunakan salah satu metodologi pengembangan berorientasi obyek (object-oriented methodology) yaitu Rational Unified Process (RUP). Unified Process (UP) dideskripsikan oleh Jacobson dkk. (1999) dalam Avison dan Fitzgerald (2006) sebagai use case driven, architectur centric, iterative and incremental. Sehingga sistem informasi yang dikembangkan akan dirancang berdasarkan use case yaitu deskripsi elemen yang memiliki fungsionalitas untuk memberikan a result of value kepada pengguna sistem. RUP dapat mengantisipasi user requirement yang tidak dapat terpenuhi seluruhnya hanya dalam satu proses / tahap pengembangan. Fase-fase dalam RUP meliputi : Inception, Elaboration, Construction, dan Transition seperti pada gambar berikut.

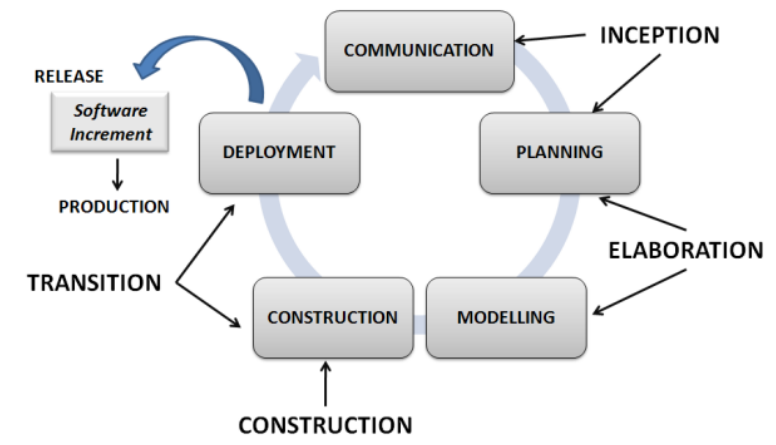

Gambar 1. Fase-fase Rational Unified Process (Pressman, 2005, hal. 97) 
Metode yang dilakukan dalam penelitian ini meliputi : studi pustaka, studi lapangan yang meliputi observasi, wawancara, dan pemotretan, eksperimen, diskusi (brainstorming), purposive sampling, determinasi, perancangan dan pembuatan modul sistem informasi.

\section{PEMBAHASAN}

Penelitian ini menggunakan data taksonomi dan hasil penelitian yang telah dipublikasikan dalam website Bank Data Obat Bahan Alam Indonesia dan website sebagai sumber informasi untuk perancangan basis data SITOBELU. Basis data dibuat berdasarkan perumusan taksonomi, fitokimia dan morfologi tanaman obat Bengkulu. Gambar berikut menunjukkan secara sederhana skema modul inventarisasi SITOBELU.

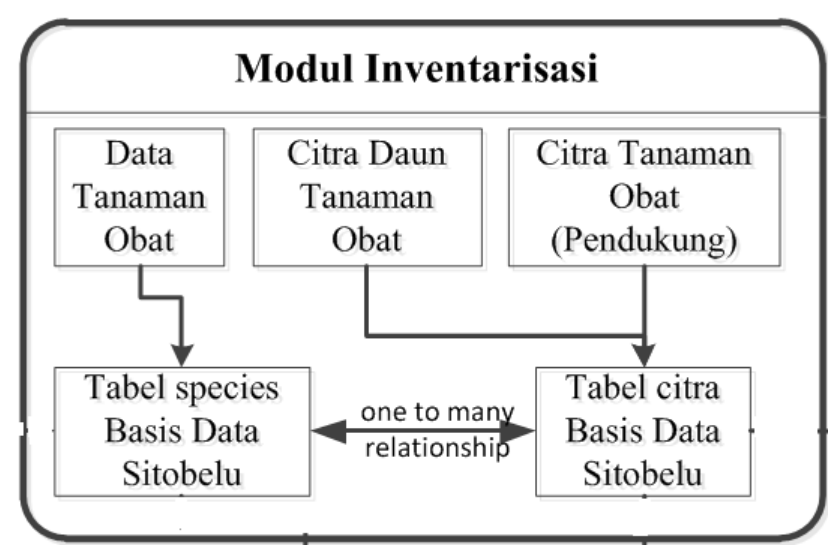

Gambar 2. Skema Modul Inventarisasi

Isian data suku dan genus mengacu pada data yang telah tersedia dalam bank data BPOM. Banyaknya suku yang digunakan yaitu 184 suku sesuai yang telah teridentifikasi dalam bank data BPOM. Struktur tabel species mengacu pada website IPTEKnet BPPT. Isian tabel species dan citra disesuaikan dengan hasil observasi dan pemotretan. Tabel user digunakan untuk mengatur otoritas pengguna yang dapat melakukan penambahan dan perubahan data dalam basis data. Pengguna tamu (guest users) hanya dapat melihat data dan melakukan pencarian berdasarkan criteria yang ditentukan admin. Proses pencarian dan perolehan (retrieval) informasi didasarkan pada bentuk citra digital daun tanaman. Modul ini berbasis web.

Hasil pemotretan berupa citra daun tanaman obat sebanyak 20 jenis spesies sebelum diupload ke dalam modul dilakukan analisis terhadap histogram citra dan edge detection. Hal ini dilakukan untuk menemukan similaritas bentuk secara sederhana sebagai pengelompokkan tanaman obat dalam modul inventarisasi. Analisis terhadap foto-foto daun tanaman tersebut dilakukan berdasarkan histogram dan edge detection tiap citra digital tanaman. Karena semua foto tanaman merupakan citra digital berwarna, yang terdiri atas channel Red, Green, Blue (RGB), maka untuk memudahkan analisis dilakukan konversi dari format RGB ke grayscale. Gambar 3 menunjukkan contoh hasil konversi tersebut untuk daun tanaman jarak pagar, daun sembung dan sirih merah.

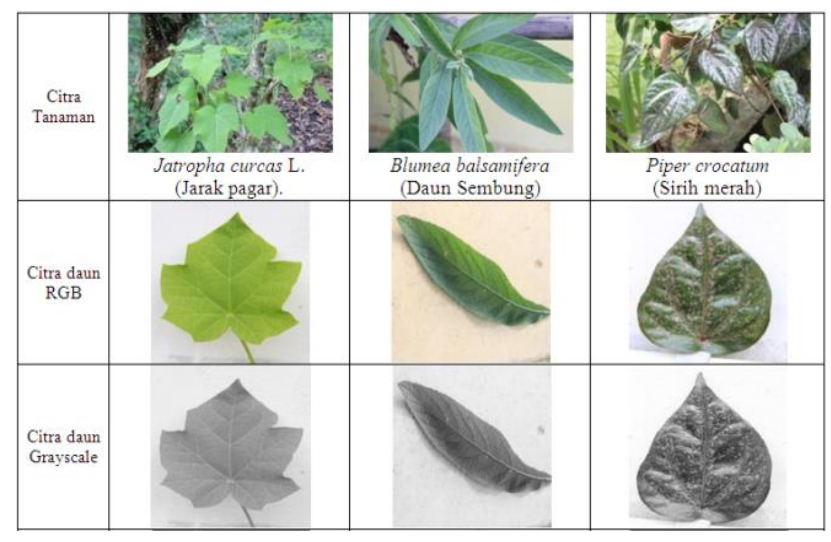

Gambar 3. Contoh citra RGB dan grayscale

Proses edge detection menggunakan metode Canny dan Sobel. Gambar 4 menunjukkan contoh hasil pengolahan citra digital terhadap citra daun tanaman obat jarak pagar, daun sembung dan sirih merah.

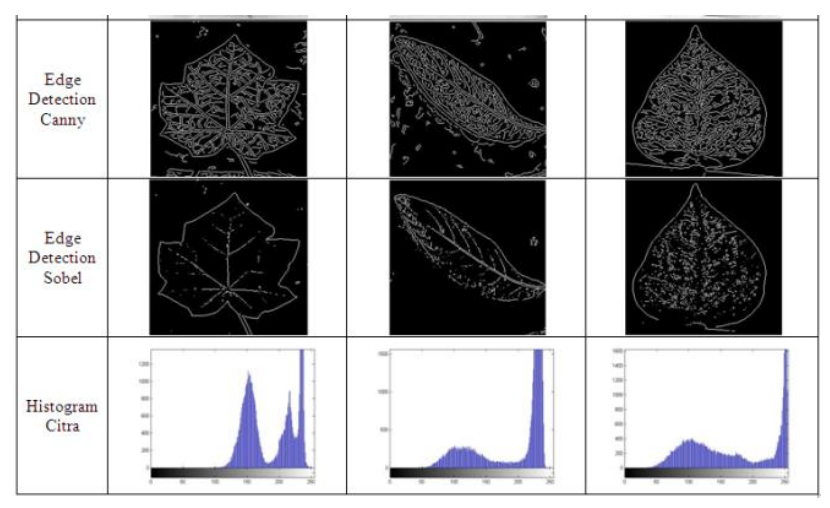

Gambar 4. Contoh hasil edge detection dan histogram citra daun

Hasil pengolahan citra digital berdasarkan histogram dan edge detection menghasilkan informasi sebagai berikut :

1) Semua citra daun yang diolah memiliki tingkat kontras yang rendah terlihat dari nilai intesitas yang tersebar tidak merata 
2) Intensitas level keabuan rendah (histogram cenderung ke kiri) ditunjukkan pada citra daun tanaman pegagan

3) Intensitas level keabuan tinggi (histogram cenderung ke kanan) ditunjukkan pada citra daun tanaman : jarak pagar, mahkota dewa, daun sembung, bangle, kumis kucing, sirih merah, keji beling, sirih, dan daun dewa.

4) Analisis terhadap hasil edge detection menunjukkan bahwa masih terdeteksi tepi lemah yang tidak relevan (selanjutnya disebut noise) dengan informasi yang dibutuhkan yaitu bentuk daun dan tulang daun.

Analisis terhadap hasil edge detection digunakan untuk pembentukan kelompok tanaman berdasarkan bentuk daun ditunjukkan pada Gambar 5.

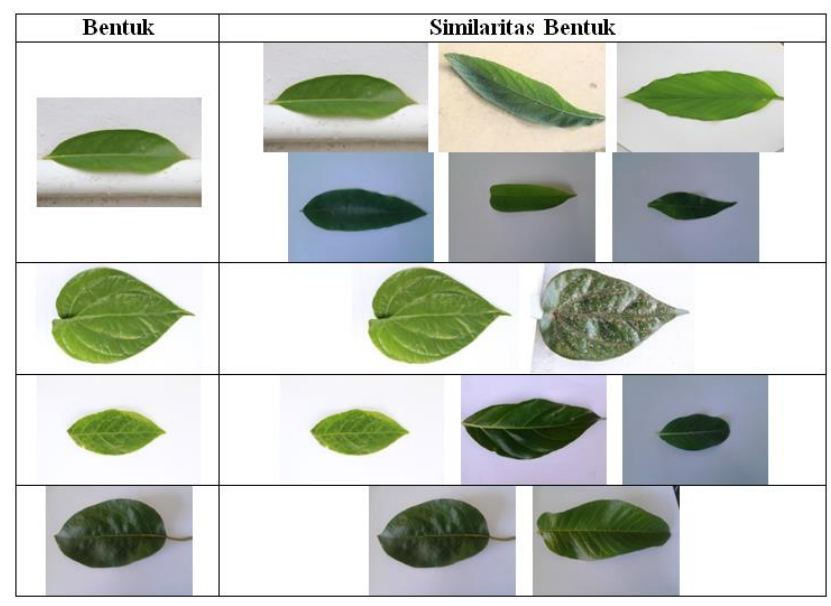

Gambar 5. Pengelompokan citra daun

Hasil pengolahan selanjutnya di-upload ke dalam modul. Gambar 6 menunjukkan tampilan halaman upload citra tanaman obat.

Untuk kebutuhan validasi algoritma retrieval, maka upload citra tanaman obat difokuskan pada karakter daun, sehingga diperoleh citra daun yang dapat digunakan sebagai key (kunci) untuk proses pencarian. Contoh tampilan halaman pencarian berdasarkan bentuk daun yang disediakan dalam modul inventarisasi SITOBELU ditunjukkan pada Gambar 7.

Selain citra daun, penelitian juga melakukan perumusan karakteristik, fitokimia dan manfaat tanaman obat Bengkulu. Perumusan dilakukan melalui studi pustaka untuk menetapkan karakter dan karakter state tanaman obat sehingga diperoleh rumusan sebagai berikut :

1) Karakter yang digunakan sebagai input basis data yaitu habitus, daun, bunga, dan buah.

2) Habitus yang digunakan yaitu : pohon, perdu, semak, dan herba
3) Karakter daun yang digunakan meliputi: kedudukan daun pada batang, tipe daun, bentuk umum (sircum scriptio), dan permukaan daun (surface)

4) Karakter bunga yang digunakan meliputi : posisi bunga, bentuk bunga, dan kelamin bunga

5) Karakter buah yang digunakan meliputi : tipe buah, bentuk buah, diameter buah, dan warna buah (muda - masak)

\section{SIMPULAN}

Penelitian ini telah menghasilkan modul inventarisasi Sistem Informasi Tanaman Obat Bengkulu yang telah dapat digunakan untuk melakukan inventarisasi tanaman obat yang keberadaannya tersedia di Kota Bengkulu. Modul ini dikembangkan dengan menggunakan prinsip contentbased image retrieval. Namun modul ini masih membutuhkan perbaikan terutama berkaitan dengan pengelompokan tanaman obat berdasarkan feature citra digital daun meliputi shape, texture, dan contour.

\section{DAFTAR PUSTAKA}

[1] Avison, David dan Fitzgerald, Guy. 2006. Information Systems Development. e/4. McGrawHill. New York.

[2] Dalimarta, S.2006. Atlas Tumbuhan Obat Indonesia. Jakarta: Trubus Agriwidya.

[3] Galingging, Ronny Yuniar. dan Bhermana, Andy. 2010. Pewilayahan Plasma Nuftah Tanaman Obat Berbasis Sistem Informasi Geografi di Kalimantan Tengah. Balai Pengkajian Teknologi Pertanian Kalimantan Tengah.

[4] Handayani. 2003. Sehat Dengan Ramuan Tradisional, Membedah Rahasia Ramuan Madura..Agromedia Pustaka:Surabaya.

[5] Hendrik dan Rahman, Ikhwanur. 2011. Pengembangan Sistem Informasi Tanaman Obat Indonesia Berbasis Liked Data. Makalah disajikan pada Seminar Nasional Teknologi Informasi 2011.

[6] Heyne, K.1987. Tumbuhan Berguna Indonesia 1. Badan penelitian dan Pengembangan Kehutanan Departemen Kehutanan. Jakarta.

[7] Muhlisah, F. 2011. Tanaman obat Keluarga. Penebar Swadaya; Jakarta.

[8] Noraziah, A., Abdella, Ahmed N., Hamid, Roslina Abdul., Sidek, Roslina Mohd., and Omardin, Mohammad Affendy. 2011. Empirical study on Medicinal Herbs Information System (MHIS) in Malaysia. African Journal of Business Management Vol. 5(13), pp. 5292-5296. (Diunduh 


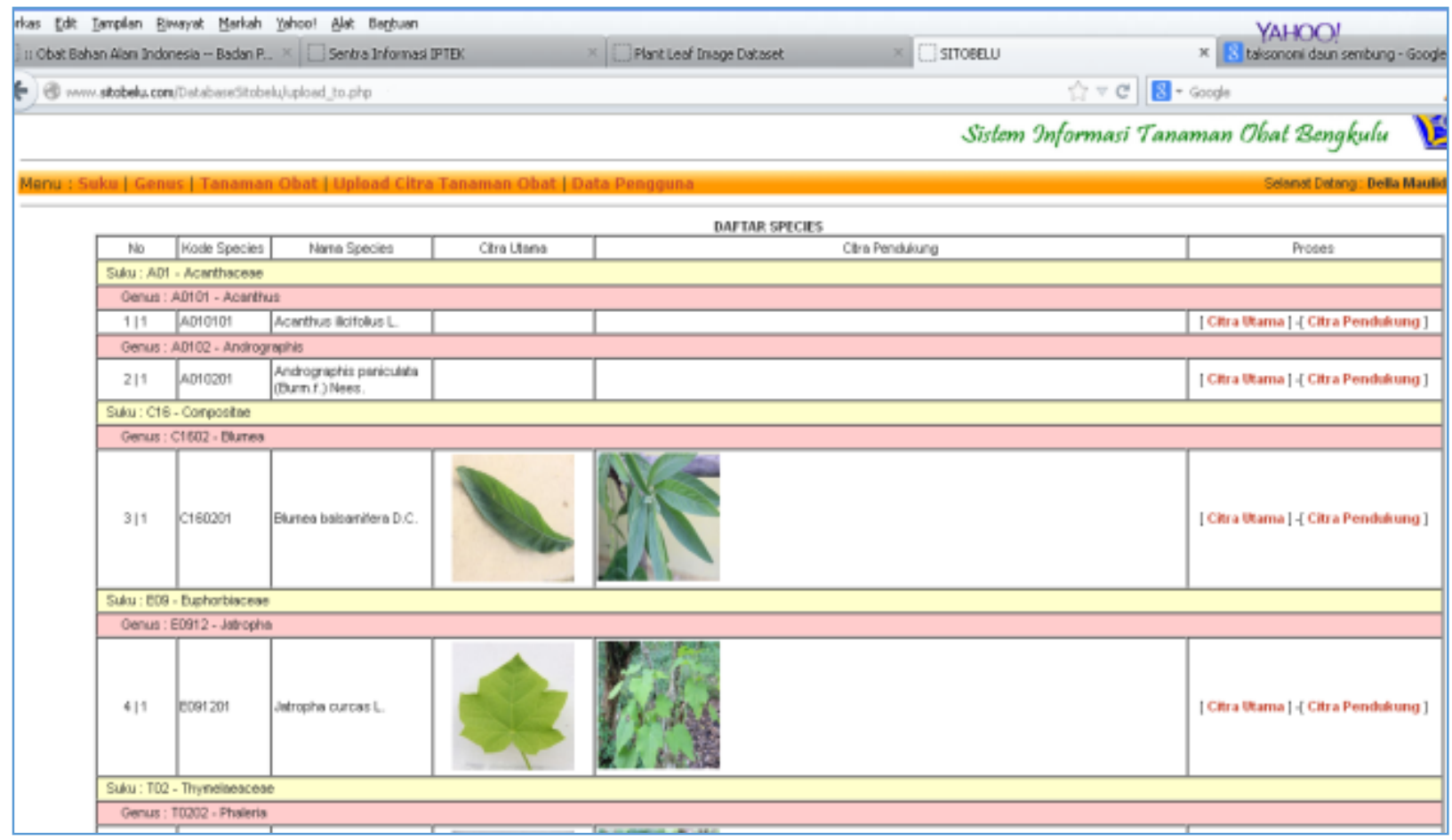

Gambar 6 Tampilan halaman upload citra

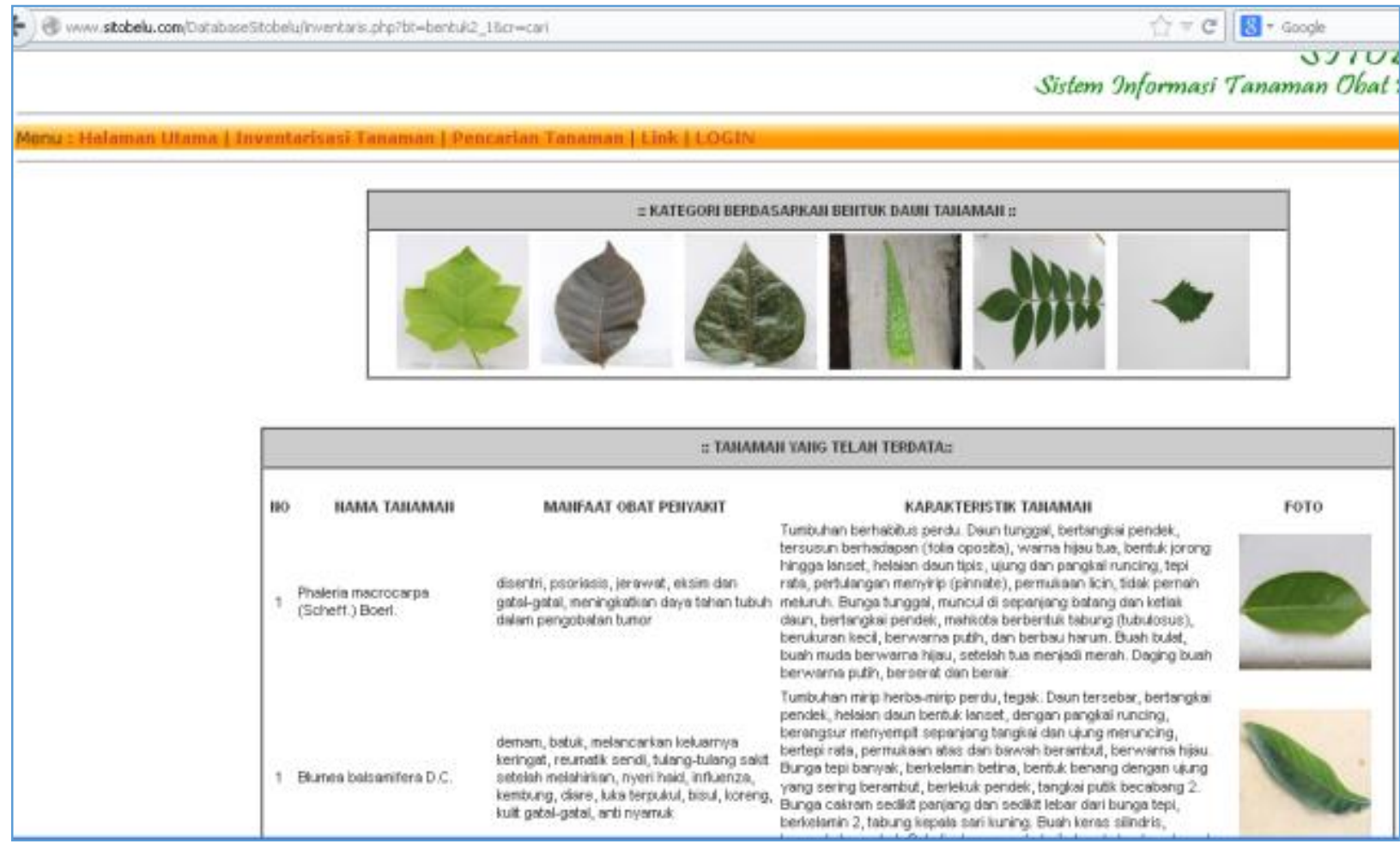

Gambar 6. Tampilan halaman pencarian

dari http://www.academicjournals.org/AJBM pada tanggal 15 Februari 2012)

[9] Nurhamidah, Kasrina.2006. Studi Etnobotani Tumbuhan Obat Tradisional dalam Naskah kuno Suku Serawai di Propinsi Bengkulu dan Survey Senyawa Bioaktifnya. Laporan Penelitian Dosen Muda FKIP. Bengkulu.
[10] Pressman, Roger S. 2005. Software Engineering: A Practitioner's Approach. McGraw-Hill. New York.

[11] Siagian,H. Mangasa. 1999. Potensi Keanekaragaman Hayati di Bengkulu Dan Hubungannya Dengan Pemanfatan Tumbuhan Sebagai Bahan Obat. Laporan Teknik Proyek Penelitian. Pusat Penelitian Dan Pengembangan Biologi. LIPI, Bogor. Di akses 11 Juni 2011.

Pengembangan Modul Inventarisasi Tanaman Obat ... 
[12] Widyaningrum, Herlina dan Tim Solusi Alternatif. 2011. Kitab Tanaman Obat Nusantara. Medpress: Yogyakarta

[13] Zuhud EAM. 2008. Potensi Hutan Tropika Indonesia Sebagai Penyangga Bahan Obat Alam Untuk Kesehatan Bangsa. http://www.iwf.or.id/ Potensihutanobat.pdf. diakses 14 Oktober 2011. 